\title{
Bioactivity studies on Zanthoxylum budrunga wall (Rutaceae) root bark
}

Md Khirul Islam ${ }^{1,2}$, Amit Kumar Acharzo ${ }^{1}$, Sanjib Saha ${ }^{1,3}$, Hemayet Hossain ${ }^{4}$, Jamil A. Shilpi ${ }^{1}$, Asish Kumar Das ${ }^{1}$ and Nripendra Nath Biswas ${ }^{1 *}$ (D)

\begin{abstract}
Background: The root-bark of the medicinally important plant Zanthoxylum budrunga (ZBRB) brooks a variety of uses in ethnobotanical and ethnomedicinal practice in Bangladesh and thus demands biological investigation to reveal its therapeutic potentiality. So, the present study was perpetrated to explore antioxidant, analgesic, antidiarrhoeal, and a cytotoxic activity of ethanolic root-bark extract of Zanthoxylum budrunga and was also to quantify the major bioactive polyphenolic constituents by HPLC analysis.
\end{abstract}

Methods: Total phenolic content was measured spectrophotometrically by using Folin Chiocalteu's reagent while in vitro antioxidant activity was determined by means of 2, 2-diphenyl-1-picrylhydrazyl (DPPH) free radical scavenging assay and reducing power assay. HPLC analysis was performed to identify and quantify the major bioactive polyphenolic constituents present in the extract. Acetic acid induced writhing test and hot-plate test were conducted to evaluate the analgesic activity of the crude extract. On the other hand, in vivo antidiarrheal potentiality was investigated by using experimentally castor oil induced diarrhoea in mice and brine shrimp lethality bio-assay was implemented to check the cytotoxic potentiality of the crude extract.

Results: Zanthoxylum budrunga showed DPPH scavenging activity $\left(\mathrm{IC}_{50} 54.27 \mu \mathrm{g} / \mathrm{mL}\right)$, while the total phenolic content was $647.91 \mathrm{mg}$ GAE/100 g of extract. ZBRB also showed concentration dependent ferric reducing power activity. At the doses of 250 and $500 \mathrm{mg} / \mathrm{kg}$, ZBRB exhibited statistically significant $(P<0.001)$ inhibition of writhing in test mice (64.58 and 77.78\%, respectively). In hot-plate test, ZBRB, at the above dose levels, significantly $(P<0.001)$ prolonged pain threshold with response time of 5.80 and $6.81 \mathrm{~s}$, respectively. In castor oil induced diarrhoeal episode in mice, ZBRB exhibited $66.56 \%$ and $83.39 \%$ inhibition of defecation at the doses of 250 and $500 \mathrm{mg} / \mathrm{kg}$, respectively $(P<0.001)$. The $L C_{50}$ (Median lethal concentration) value of ZBRB in brine shrimp lethality bioassay was found to be 21 . $84 \mu \mathrm{g} / \mathrm{mL}$. In the HPLC analysis, (+)-catechin, caffeic acid and quercetin were detected with the concentration of 17. $94 \mathrm{mg} / 100,3.72 \mathrm{mg} / 100$ and $11.95 \mathrm{mg} / 100 \mathrm{~g}$ of ethanolic extract of ZBRB, respectively.

Conclusion: The results rationalize the uses of the plant in traditional medicine for diarrhoeal as well as pain management. Catechin, caffeic acid, and other phenolics constituents might have some function in the observed activity.

Keywords: Zanthoxylum, Root-bark extracts, HPLC analysis, Antioxidants, Antidiarrheals, Cytotoxins

\footnotetext{
* Correspondence: utsadipon@gmail.com; nnathbiswas@gmail.com

${ }^{1}$ Pharmacy Discipline Life Science School, Khulna University, Khulna 9208,

Bangladesh

Full list of author information is available at the end of the article
} 


\section{Background}

Zanthoxylum budrunga Wall (Syn: Zanthoxylum rhesta Roxb.) belongs to the family Rutaceae. It is a medium sized deciduous tree, $12-30 \mathrm{~m}$ tall and native to subtropical areas. It has armed branches with ascending or straight prickles. In Bangladesh it is called "Bajna" and widely found in Sylhet, Chittagong hill tracts, Cox's Bazar, Gazipur and Tangail $[1,2]$. It also grows in Thailand, Malaysia, Sri Lanka, Myanmar, Indo-China, Philippines, Java, India and Papua New Guinea. The stem bark and fruits are aromatic, astringent, carminative, antiemetic, stimulant and prescribed with honey in rheumatism. Essential oil of leaves is used in cholera and juice of the bark is beneficial in cough, dysentery, vomiting and headache [2]. Previously, quinazoline alkaloids, and a monoterpene triol named trihydroxy- $p$-menthane were isolated from $Z$. budrunga [3]. The antimicrobial and cytotoxic activity of chloroform extract of the bark was evaluated and reported [4]. Thirty four compounds including terpinen-4-ol, $\alpha$-terpineol, sabinene, $\beta$-phellandrene and 2-undecanone were identified in the volatile oil of $Z$. budrunga seed coat [5]. As no evaluations have been reported on the root bark of $Z$. budrunga so far prompt us to investigate antioxidant, analgesic, antidiarrheal, cytotoxic activity and HPLC profiling of the ethanol crude extract of the aforementioned plant parts to justify the medicinal use of this part as cholinergic and spasmolytic agent [6].

\section{Methods}

\section{Chemicals and reagents}

Gallic acid, ascorbic acid, tricholoroacetic acid, potassium ferricyanide, ferric chloride, acetic acid, sodium monobasic phosphate, sodium dibasic phosphate, sodium carbonate and sodium chloride were purchased from Merck, Germany. DPPH, Folin-Chiocalteu's reagent was obtained from Sigma-Aldrich, USA. Vincristine sulphate was collected from Cipla, India, diclofenac sodium from Beximco Pharmaceuticals Ltd., Bangladesh, and morphine from popular Pharmaceuticals Ltd., Bangladesh. For HPLC analysis, 11 (eleven) known phenolic compounds, gallic acid (GA), (+)-catechin hydrate (CT), vanillic acid (VA), caffeic acid (CA), (-)-epicatechin (EC), p-coumaric acid (PCA), rutin hydrate $(\mathrm{RH})$, ellagic acid (EA), myricetin $(\mathrm{MC})$, kaempferol (KF) and quercetin (QU) were used and procured from Sigma-Aldrich (St. Louis, MO, USA). Solvents used as mobile phase in HPLC were acetonitrile (HPLC grade), methanol (HPLC grade) and acetic acid (HPLC grade) was purchased from Merck (Germany).

\section{Plant material and extraction procedure}

The root bark of $Z$. budrunga was collected from Tangail, Bangladesh in September' 2011. The plant materials were authenticated by the experts at Bangladesh
National Herbarium, Dhaka, Bangladesh. For further reference, a voucher specimen (DACB 37522) has been submitted. The root-barks were washed and separated from other plant materials as well as chopped into small pieces following shed drying. The dried root barks were ground into a fine powder with the help of a mechanical grinder and macerated in $95.00 \%$ ethanol for 2 days with occasional shaking and stirring. It was filtered through a cotton plug to collect clear filtrate. Solvent was evaporated from the filtrate to get the crude extract. The root bark yielded $1.35 \%$ extract of dried plant material.

\section{Experimental animal}

Young Swiss-Albino mice (aged 3-4 weeks and weight 20-25 g) were collected from International Centre for Diarrhoeal Disease and Research, Bangladesh (ICCDR, B) and randomly selected for the pharmacological investigations. The mice were provided with commercial rodent pellet food and water ad libitum. Mice were housed in clean and well-ventilated cages under standard environmental condition where $12 \mathrm{~h}$ light and $12 \mathrm{~h}$ dark cycle was maintained with relative humidity $55-60 \%$ and room temperature $25 \pm 2{ }^{\circ} \mathrm{C}$. Before starting the pharmacological experiments, mice were accommodated to adjust with the environment for 7 days. All experimental protocols were in compliance with the ethical guideline approved by ethical committee at Pharmacy Discipline, Khulna University.

\section{Phytochemical analysis}

Standard qualitative phytochemical group tests were performed to trace major groups of secondary bioactive metabolites present in crude ethanolic extract following the standard procedures described by Ghani [7].

\section{DPPH radical scavenging activity}

The method adopted by Biswas [8] was followed to quantify in vitro free radical scavenging activity of the prepared plant extracts. Different concentrations $(512 \mu \mathrm{g} /$ $\mathrm{mL}, 128 \mu \mathrm{g} / \mathrm{mL}, 64 \mu \mathrm{g} / \mathrm{mL}, 32 \mu \mathrm{g} / \mathrm{mL}, 16 \mu \mathrm{g} / \mathrm{mL}, 8 \mu \mathrm{g} /$ $\mathrm{mL}, 4 \mu \mathrm{g} / \mathrm{mL}, 2 \mu \mathrm{g} / \mathrm{mL}$ and $1 \mu \mathrm{g} / \mathrm{mL}$ ) of ZBRB were prepared by serial dilution and $1 \mathrm{~mL}$ of that of each concentration was taken into a test tube followed by the addition of $3 \mathrm{~mL}$ of $0.004 \%(w / v)$ solution of DPPH in ethanol. The mixture was homogenised by shaking vigorously and incubated in a dark place for $30 \mathrm{~min}$ at room temperature to promote reaction. The extant of antioxidant capacity of test extract was measured by recording the absorbance (optical density-OD) of each resulting solution with the help of UV spectrophotometer for each against a blank at $517 \mathrm{~nm}$ [8]. The experiment was duplicated for more accuracy. The commercial known antioxidant, ascorbic acid, was allowed to react with DPPH and recorded the absorbance in same manner for comparison 
with plant crude extract. DPPH radical scavenging activity was calculated using the following formula:

$$
\begin{aligned}
\text { scavenging activity }(\%)= & 1-\left(\frac{\text { absorbance of sample }}{\text { absorbance of control }}\right) \\
& \times 100
\end{aligned}
$$

\section{Total phenolic content}

ZBRB was weighed $(0.50 \mathrm{~g})$ and dissolved in $50 \mathrm{~mL}$ of $80 \%$ aqueous methanol and sonicated for $20 \mathrm{~min}$ in ultrasonic bath. From the mixture, $2 \mathrm{~mL}$ was taken and centrifuged for $15 \mathrm{~min}$ at $14000 \mathrm{rpm}$. The amount of total phenolics present in the extract was measured by Folin Ciocalteu's reagent [9]. A standard curve was prepared using gallic acid solutions of $15.63 \mathrm{mg} / \mathrm{mL}$, $31.25 \mathrm{mg} / \mathrm{mL}, 62.50 \mathrm{mg} / \mathrm{mL}, 125.00 \mathrm{mg} / \mathrm{mL}, 250.00 \mathrm{mg} /$ $\mathrm{mL}$ and $500.00 \mathrm{mg} / \mathrm{mL}$ in methanol. Extract and each of the concentrations of gallic acid solutions ( $1 \mathrm{~mL}$ each) were transferred into $25 \mathrm{~mL}$ volumetric flasks containing $9 \mathrm{~mL}$ of distilled water. Upon continuous shaking, $1 \mathrm{~mL}$ of Folin Ciocalteu's reagent was added to each volumetric flask. After an interval of $5 \mathrm{~min}, 10.00 \mathrm{~mL}$ of $7.00 \%$ $\mathrm{Na}_{2} \mathrm{CO}_{3}$ was added each volumetric flask and the volume was adjusted to $25.00 \mathrm{~mL}$ with distilled water. After incubation at room temperature for $30 \mathrm{~min}$, absorbance was recorded at $750 \mathrm{~nm}$. Blank was prepared following the above procedures without gallic acid or extract. Standard curve was prepared by plotting the absorbance versus concentration of gallic acid solutions. Total phenolic content of ZBRB was expressed as the gallic acid equivalent per $100 \mathrm{~g}$ of extract.

\section{Reducing power assay}

Ferric reducing power of the extract was determined by the method of Oyaizu [10]. ZBRB or ascorbic acid solutions of $1 \mathrm{~mL}$ having concentrations of $15.63 \mu \mathrm{g} / \mathrm{mL}$, $31.25 \mu \mathrm{g} / \mathrm{mL}, 62.50 \mu \mathrm{g} / \mathrm{mL}, 125.00 \mu \mathrm{g} / \mathrm{mL}, 250.00 \mu \mathrm{g} / \mathrm{mL}$ and $500.00 \mu \mathrm{g} / \mathrm{mL}$ were mixed with $2.50 \mathrm{~mL}$ of $1 \%$ potassium ferricyanide and $2.50 \mathrm{~mL}$ of phosphate buffer $(0.20 \mathrm{M}, \mathrm{pH} 6.60)$ with continuous shaking. The mixture was then incubated at $50{ }^{\circ} \mathrm{C}$ for $20 \mathrm{~min}$ in incubator. After that, $2.50 \mathrm{~mL}$ of trichloroacetic acid $\left[\mathrm{CCl}_{3} \mathrm{COOH}\right]$ $(10.00 \%)$ was added to the mixture and centrifuged for $10 \mathrm{~min}$ at $3000 \mathrm{rpm}$. An aliquot of the supernatant $(2.50 \mathrm{~mL})$ was mixed with $0.50 \mathrm{~mL}$ of ferric chloride $(0.10 \%)$ with vigorous shaking. After $5 \mathrm{~min}$, absorbance was recorded at $700 \mathrm{~nm}$. Reducing power of ZBRB and ascorbic acid were expressed by plotting absorbance against concentration.

\section{HPLC detection of phenolics}

HPLC analysis was carried out to detect and determine some of the commonly occurring bioactive phenolic compounds in ZBRB [11]. The investigation was conducted on a Dionex UltiMate 3000 system fitted with quaternary rapid separation pump (LPG-3400RS) and photodiode array detector (DAD-3000RS). Separation was done on a Acclaim $\mathrm{C}_{18}(5.00 \mu \mathrm{m})$ Dionex column $(4.60 \times 250.00 \mathrm{~mm})$ at $30^{\circ} \mathrm{C}$ with a flow rate of $1.00 \mathrm{~mL} /$ min and an injection volume of $20.00 \mu \mathrm{l}$. Acetonitrile (solvent A), acetic acid solution $\mathrm{pH} 3.00$ (solvent B) and methanol (solvent $\mathrm{C}$ ) was mixed in various proportions to prepare mobile phase for the gradient elution programme of A: B (5.00: $95.00, v / v)(0-9 \mathrm{~min}), \mathrm{A}: \mathrm{B}: \mathrm{C}$ (10.00: 80.00: 10.00, v/v/v) (10-19 min), and A: B: C (20.00: 60.00: 20.00, v/v/v) (20-30 min) with post run equilibration of the system with $100 \%$ A (5 min). Initially, the UV detector was fixed to $280 \mathrm{~nm}$ for $18 \mathrm{~min}$, changed to $320 \mathrm{~nm}$ for consecutive $6 \mathrm{~min}$, and finally to $380 \mathrm{~nm}$ and apprehended for the rest of the analysis period while the diode array detector was set at an acquisition range from $200 \mathrm{~nm}$ to $700 \mathrm{~nm}$ for the entire run time. The mixed standard solution was prepared in methanol having the concentration of $5.00 \mu \mathrm{g} / \mathrm{mL}$ for GA, $\mathrm{CH}, \mathrm{VA}, \mathrm{CA}, \mathrm{EC}, \mathrm{PCA}, \mathrm{EA}, \mathrm{MC}, \mathrm{KF}, 4.00 \mu \mathrm{g} / \mathrm{mL}$ for RU, and $3.00 \mu \mathrm{g} / \mathrm{mL}$ for QU. ZBRB solution was prepared in methanol having a concentration of $5.00 \mathrm{mg} / \mathrm{mL}$. Both standard and ZBSB solution were filtered through 0.20 $\mu \mathrm{m}$ nylon syringe filter (Sartorius, Germany) and degassed in an ultrasonic bath (Hwashin, Korea) for 15 min prior to the HPLC analysis. Data accumulation, peak assimilation and calibrations were performed using Dionex Chromeleon software (Version 6.80 RS 10).

\section{Evaluation of analgesic activity Writhing test}

The extract was subjected to acetic induced writhing test in mice according to the method described by Anisuzzman M [12]. Experimental mice were randomly screened and separated into four groups with six mice in each. Each mouse was placed in separate transparent polyvinyl cage. In the present study, ZBRB was administered at the doses of 250 and $500 \mathrm{mg} / \mathrm{kg}$. Positive control group was served with diclofenac sodium $(25 \mathrm{mg} / \mathrm{kg}$ ) while the control group received $1 \%$ tween-80 in distilled water at the dose of $10 \mathrm{~mL} / \mathrm{kg}$. All treatments were administered orally with the help of a feeding needle. To induce abdominal contraction, $0.70 \%$ acetic acid solution was injected intraperitonially after $30 \mathrm{~min}$ of each treatment. After 5 min (due to promote better absorption of acetic acid), abdominal contraction or writhing was counted for $10 \mathrm{~min}$. Analgesic activity was expressed as the \% inhibition of writhing as compared to control.

\section{Hot-plate test}

Hot-plate test was adopted to measure the pain threshold according to the method of Mondal [13]. In hot- 
plate test, mice of either sex were arbitrarily selected and divided into four groups, six mice each. Mice of control group were administered $1.00 \%$ tween- 80 in distilled water at dose of $10 \mathrm{~mL} / \mathrm{kg}$ body weight where, mice of positive control group were given morphine at dose of $5 \mathrm{mg} / \mathrm{kg}$ body weight and mice of test group were received the extract at two different doses of 250 and $500 \mathrm{mg} / \mathrm{kg}$ body weight. All doses were administered orally by using a clean sterile feeding needle. Mice were placed on hot plate maintained at $55 \pm 0.5{ }^{\circ} \mathrm{C}$ to measure the response time. A cut-off point of $15 \mathrm{~s}$ was used to avoid injury to the paws of mice. Time taken to lick the hind and fore paws or jump was considered as the response time and recorded at $0,30,60,90$ and $120 \mathrm{~min}$.

\section{Evaluation of antidiarrheal activity}

In vivo antidiarrheal activity was investigated by castor oil induced diarrhoea model in mice [12]. Mice were screened based on their sensitivity to castor oil induced diarrhoea and divided into four groups containing six mice in each. The extract was administered at the doses of 250 and $500 \mathrm{mg} / \mathrm{kg}$. Positive control group was received loperamide $(3 \mathrm{mg} / \mathrm{kg})$ as the reference drug and control group was treated with $1.00 \%$ tween- 80 in distilled water. All doses were given orally with the help of feeding needle. After $1 \mathrm{~h}$ of oral treatment, each mouse was administered orally with $0.50 \mathrm{~mL}$ castor oil with the help of feeding needle to induce diarrhoea. Each mouse was housed in separate transparent polyvinyl cage. The floor of the cage was lined with white blotting paper for the ease of counting stools and was changed every hour up to the observation period of $4 \mathrm{~h}$. The appearance of first stool as well as total number of stool over the entire observation period was used to determine latency and percentage (\%) inhibition of defecation.

\section{Brine shrimp lethality bioassay}

Conventional toxicity of the crude ethanolic extract of ZBRB was determined by brine shrimp (Artemia salina) lethality bioassay developed by Meyer et al. [14]. Artificial sea water was prepared by dissolving $18.00 \mathrm{~g}$ of table salt and $20.00 \mathrm{~g}$ of pure $\mathrm{NaCl}$ in one litre of distilled water to hatch shrimp eggs into brine shrimp nauplii. It was kept in a rectangular tank of two compartments with perforated divider. Brine shrimp eggs leach were taken into the larger dark compartment. Oxygen supply was maintained continuously by electric air pump and hatching was performed at constant temperature $\left(25-30{ }^{\circ} \mathrm{C}\right)$ for $24-48 \mathrm{~h}$. After hatching, matured nauplii were collected from the lightened compartment. In this test, ZBRB suspensions of various concentrations $(320.00 \mu \mathrm{g} / \mathrm{mL}, 160.00 \mu \mathrm{g} / \mathrm{mL}, 80.00 \mu \mathrm{g} / \mathrm{mL}$, $40.00 \mu \mathrm{g} / \mathrm{mL}, 20.00 \mu \mathrm{g} / \mathrm{mL}, 10.00 \mu \mathrm{g} / \mathrm{mL}, 5.00 \mu \mathrm{g} / \mathrm{mL}$ ) were prepared in distilled water by serial dilution technique and $5.00 \mathrm{~mL}$ of each concentration containing 10 nauplii was taken into test tubes. DMSO (Dimethyl sulfoxide) was used to assist in mixing ZBSB with water where the concentration of DMSO did not exceed $0.10 \%$ and saline water containing $0.10 \%$ DMSO was considered as the control. Vincristine sulphate was used at different concentrations of $5.00 \mu \mathrm{g} / \mathrm{mL}, 2.50 \mu \mathrm{g} / \mathrm{mL}, 1.25 \mu \mathrm{g} / \mathrm{mL}$, $0.60 \mu \mathrm{g} / \mathrm{mL}$ and $0.30 \mu \mathrm{g} / \mathrm{mL} \mu \mathrm{g} / \mathrm{mL}$ and served as the positive control. All the test tubes were kept at room temperature $\left(25-30{ }^{\circ} \mathrm{C}\right)$ for $24 \mathrm{~h}$ and number of alive nauplii was counted with the help of a magnifying glass.

\section{Statistical analysis}

All results of the present study were expressed as mean \pm SEM (standard error mean). Statistical analysis was carried out using Student's t-test, one-way ANOVA followed by Dunnett post-hoc test, and two-way analysis of ANOVA followed by.

Bonferroni's test. Analysis was performed in Prism 5.0 (GraphPad software Inc., San Diego, CA). Results were considered as significant when $P$ value is less than 0.05 . The $\mathrm{LC}_{50}$ value of $\mathrm{ZBRB}$ in brine shrimp lethality bioassay was determined by using Probit analysis software (LdP Line software, USA).

\section{Results}

\section{Phytochemical analysis}

In phytochemical screening, ZBRB showed the presence of flavonoids, alkaloids, glycosides, steroids, gums, reducing sugars and tannins (Table 1).

\section{DPPH radical scavenging activity}

In the DPPH radical scavenging activity test, ZBRB and ascorbic acid showed radical scavenging activity with the $\mathrm{IC}_{50}$ values of $54.27 \mu \mathrm{g} / \mathrm{mL}$ and $11.81 \mu \mathrm{g} / \mathrm{mL}$, respectively. Both, ZBRB and ascorbic acid showed a concentration dependent DPPH radical scavenging activity within the concentration range tested (Fig. 1).

Table 1 Phytochemical screening of ZBRB

\begin{tabular}{lc}
\hline Phytochemical groups & Result \\
\hline Flavonoids & + \\
Alkaloids & + \\
Glycosides & + \\
Steroids & + \\
Gums & + \\
Saponins & - \\
Reducing sugars & + \\
Tannins & + \\
\hline
\end{tabular}

$+=$ Present. - = absence 


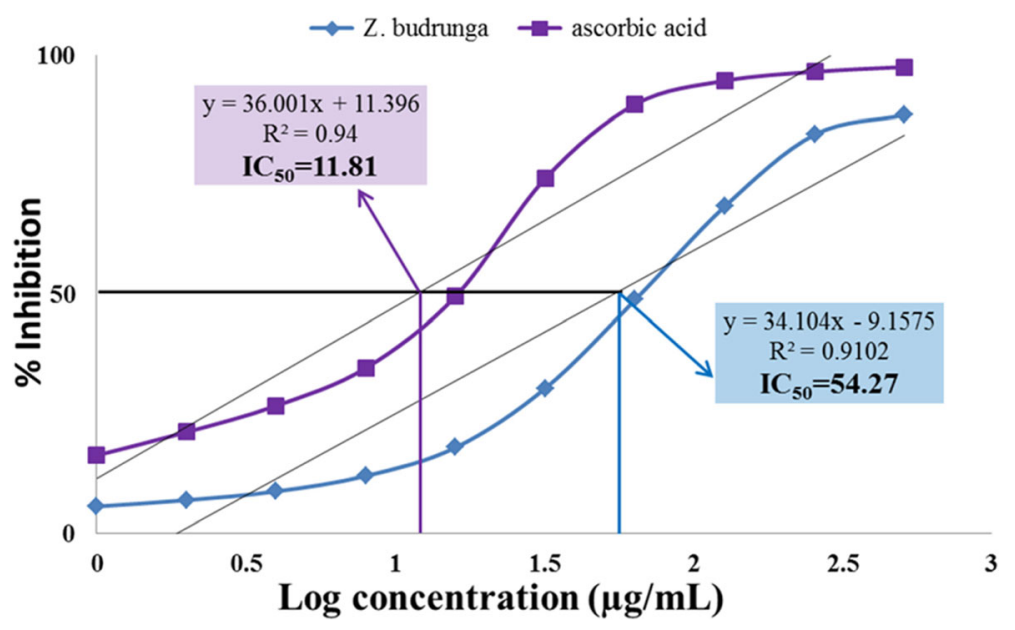

Fig. 1 DPPH scavenging activity of ZBRB

\section{Total phenolic content}

A linear regression equation, $y=0.0963 x+0.0036 ; R^{2}=$ 0.9878 , obtained from a calibration curve of absorbance values of different concentrations of gallic acid was used to calculated total phenolic content of crude extract and what was found to be 647.91 GAE/100 g extract (Fig. 2).

\section{Reducing power assay}

ZBRB showed a concentration dependant moderate ferric reducing power (measured by recording the absorbance) as compared to ascorbic acid, used as the reference standard in this assay. The ZBRB concentrations of $15.63 \mu \mathrm{g} /$ $\mathrm{mL}, 31.25 \mu \mathrm{g} / \mathrm{mL}, 62.50 \mu \mathrm{g} / \mathrm{mL}, 125.00 \mu \mathrm{g} / \mathrm{mL}, 250.00 \mu \mathrm{g} /$ $\mathrm{mL}$ and $500.00 \mu \mathrm{g} / \mathrm{mL}$, showed absorbance of $0.55,0.69$, $0.77,0.82,0.96$ and 1.08 , respectively and ascorbic acid showed absorbance of $0.71,0.89,1.14,1.54,2.42$ and 2.87 at same concentrations (Fig. 3).

\section{HPLC detection of phenolics}

Among the 11 (eleven) phenolic compounds screened, CT, CA and QU were found to be present in ZBRB with the concentrations of $17.94 \mathrm{mg} / 100 \mathrm{~g}, 3.72 \mathrm{mg} / 100 \mathrm{~g}$ and $11.95 \mathrm{mg} / 100 \mathrm{~g}$ ethanolic extract of ZBRB, respectively. GA, VA, EC, PCA, RU, EA, MC and KF were absent or were present in a trace amount beyond the detection level (Figs. 4 \& 5; Tables 2 and 3).

\section{Evaluation of analgesic activity Writhing test}

ZBRB showed significant decrease in number of writhes dose dependently as compared to control. At the doses of 250 and $500 \mathrm{mg} / \mathrm{kg}$, the extract showed $64.58 \%$ and $77.43 \%$ writhing inhibition respectively $(P<0.001)$. Diclofenac sodium, used as the positive control, also decreased

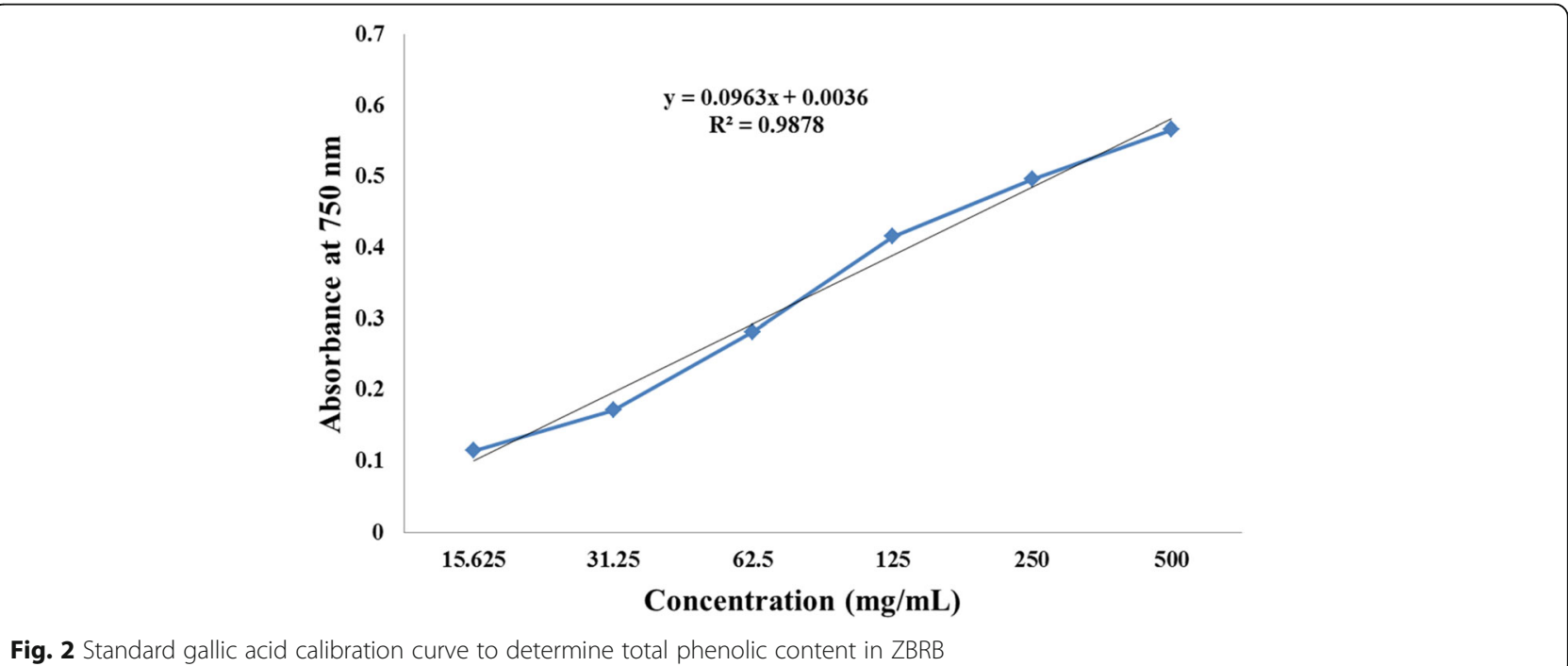

Fig. 2 Standard gallic acid calibration curve to determine total phenolic content in ZBRB 


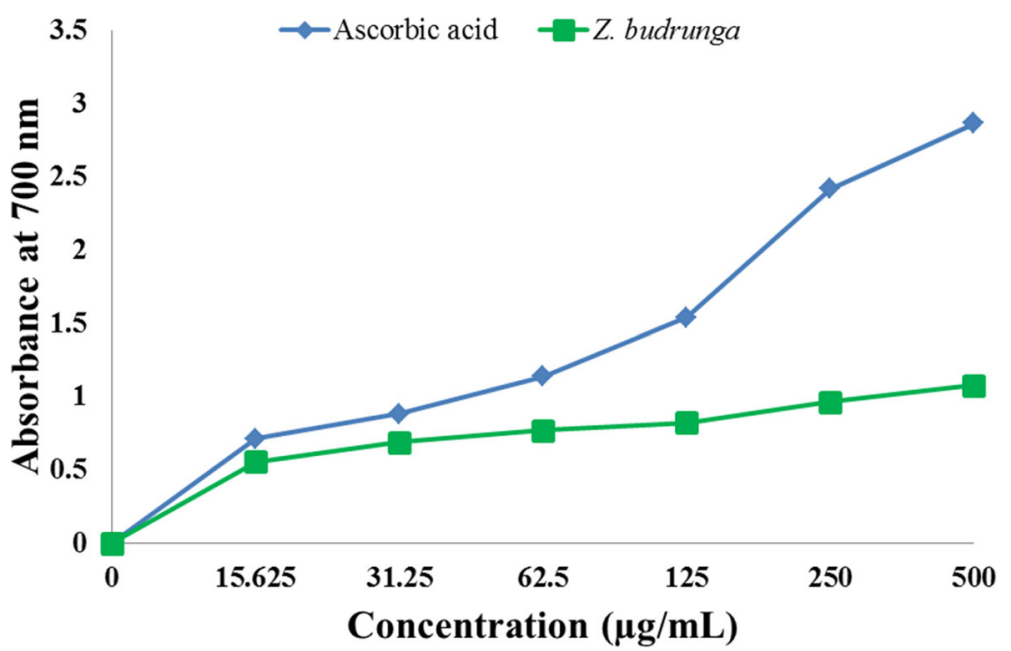

Fig. 3 Reducing power of the ethanol extract of ZBRB

the number of writhes (81.95\% inhibition) with statistical $(P<0.001)$ significance (Fig. 6).

\section{Hot-plate test}

Oral administration of crude extract with two different doses of 250 and $500 \mathrm{mg} / \mathrm{kg}$ increased response time (5.80 and $6.81 \mathrm{~s}$ ) to pain stimulus as compared to control (3.29 s) in hot plate test (Fig. 7). Morphine $(5.00 \mathrm{mg} / \mathrm{kg})$ exhibited maximum reaction time of $9.60 \mathrm{~s}$ at $90 \mathrm{~min}$. The results of the extract and morphine were statistically significant $(P<0.001)$.

\section{Evaluation of antidiarrheal activity}

The extract of ZBRB exhibited significant antidiarrhoeal activity. The extract showed marked increase in latent period and decrease in number of stools as compared to control in dose dependent manner (Table 4). At the doses of 250 and $500 \mathrm{mg} / \mathrm{kg}$, the extract showed $66.56 \%$ and $83.39 \%$ inhibition of defecation respectively whereas the standard drug Loperamide $(3 \mathrm{mg} / \mathrm{kg}$ ) which comparatively showed $89.56 \%$ inhibition of defecation. All of the result was found to be statistically significant $(P<0.001)$.

\section{Brine shrimp lethality bioassay}

ZBRB exhibited lethality against nauplii in a concentration dependent manner with an $\mathrm{LC}_{50}$ of $21.84 \mu \mathrm{g} / \mathrm{mL}$ while that of vincristine sulphate was $0.53 \mu \mathrm{g} / \mathrm{mL}$ (Figs. 8 and 9). LdP line probit analysis software, USA was used to determine $\mathrm{LC}_{50}$ values.

\section{Discussion}

Plants used in traditional medicine serves as one of the major source of bioactive compounds. From the above results of different tests it can be demonstrated that the

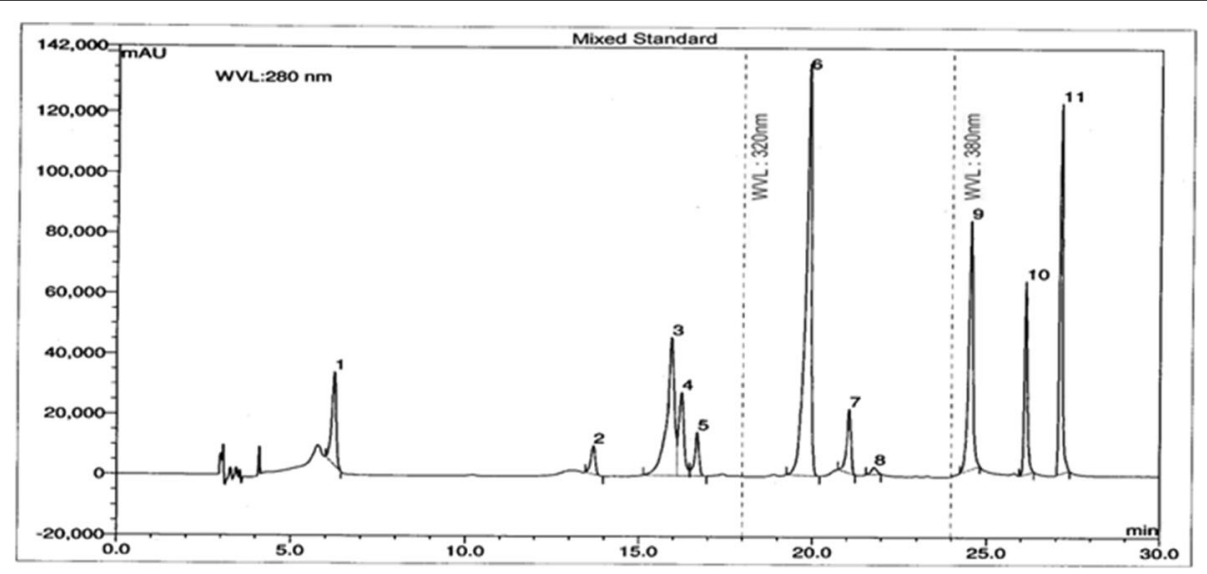

Fig. $4 \mathrm{HPLC}$ chromatogram of a standard mixture of polyphenolic compounds. Here peaks indicate, 1: GA, 2: CT, 3: VA, 4: CA, 5: EC, 6: PCA, 7: RU, 8: EA, 9: MC, 10: QU, 11: KF. Figure Sign: 1= gallic acid (GA), 2=(+)-catechin hydrate (CT), 3=vanillic acid (VA), 4=caffeic acid (CA), 5=(-)-epicatechin (EC), 6=p-coumaric acid (PCA), 7=rutin hydrate (RH), $8=$ =ellagic acid (EA), 9=myricetin (MC), 10=quercetin (QU) and 11=kaempferol (KF) 
Table 2 Parameters of calibration graphs for the eleven phenolic standards used

\begin{tabular}{|c|c|c|c|c|c|c|}
\hline Peak no. & Polyphenolic compound & $\begin{array}{l}\text { Linearity range } \\
(\mu \mathrm{g} / \mathrm{mL})\end{array}$ & Correlation coefficients $\left(r^{2}\right)$ & $\begin{array}{l}\text { Detection limit } \\
(\mu \mathrm{g} / \mathrm{mL})^{\mathrm{a}}\end{array}$ & $\begin{array}{l}\text { Quantitation limit } \\
(\mu \mathrm{g} / \mathrm{mL})^{a}\end{array}$ & Recovery $(\%)^{k}$ \\
\hline 1 & GA & $1.00-5.00$ & 0.9951 & 0.20 & 0.65 & $97.30 \pm 1.99$ \\
\hline 2 & CT & $0.50-4.00$ & 0.9972 & 0.10 & 0.38 & $97.50 \pm 1.81$ \\
\hline 3 & VA & $1.00-5.00$ & 0.9948 & 0.21 & 0.72 & $96.40 \pm 1.04$ \\
\hline 4 & CA & $0.50-4.00$ & 0.9950 & 0.14 & 0.47 & $97.90 \pm 1.02$ \\
\hline 5 & EC & $1.00-5.00$ & 0.9959 & 0.28 & 0.85 & $98.20 \pm 2.84$ \\
\hline 6 & PCA & $1.00-5.00$ & 0.9982 & 0.26 & 0.90 & $102.90 \pm 2.65$ \\
\hline 7 & $\mathrm{RU}$ & $0.50-4.00$ & 0.9976 & 0.13 & 0.45 & $101.30 \pm 2.90$ \\
\hline 8 & EA & $1.00-5.00$ & 0.9990 & 0.29 & 0.92 & $97.20 \pm 2.08$ \\
\hline 9 & $M C$ & $1.00-5.00$ & 0.9981 & 0.29 & 0.92 & $98.20 \pm 3.01$ \\
\hline 10 & QU & $0.25-3.00$ & 0.9972 & 0.07 & 0.24 & $100.20 \pm 3.13$ \\
\hline 11 & KF & $1.00-5.00$ & 0.9991 & 0.27 & 0.86 & $101.50 \pm 3.54$ \\
\hline
\end{tabular}

${ }^{a}$ Data were expressed as mean of triplicate measurements

${ }^{\mathrm{b}}$ Recovery are expressed as mean \pm standard deviation carried out on ethanol extract of ZBRB

ethanol extract of ZBRB possess potential antioxidant, analgesic, antidiarrhoeal and cytotoxic activities.

The antioxidant activity of plants can contribute towards a healthy immune system and prevent many diseases. Daily ingestion of antioxidant rich diet can significantly reduce the chance of cancer by protecting our body from the damage caused by free radicals $[15,16]$. The antioxidant compounds reportedly show antioxidant activity through either by scavenging the reactive oxygen species or by boosting antioxidant defence mechanisms of our body [8]. DPPH is a stable free radical which undergoes decolourization from deep violet to light yellow with concentration dependent manner upon reaction with antioxidant compound under test [17]. So, the conterminously decolourization and drop-off absorbance of DPPH solution with crude ethanolic extract in concentration dependent manner substantiate the antioxidant activity of the extract in comparison with standard, gallic acid (Fig. 1). This antioxidant activity might be claimed to the presence of polyphenolic compounds in the extract [8]. However, there is a direct correlation between phenolic content and antioxidant activity because of the scavenging ability of hydroxy groups as they are effective hydrogen donor or electron acceptor $[18,19]$. Folin Ciocalteu's reagent was used to determine the total phenolic content of the extract (Fig. 2). Further, ZBRB showed a concentration dependant moderate ferric reducing power (Fig. 3) in comparison with ascorbic acid that was assessed to elaborate its antioxidant activity. Reducing power serves as a significant and sensitive parameter to assess potential antioxidant activity of plant extracts [20]. In reducing power assay, antioxidants reduce potassium ferricyanide $\left(\mathrm{Fe}^{3+}\right)$ into potassium ferrocyanide $\left(\mathrm{Fe}^{2+}\right)$. Upon addition of ferric

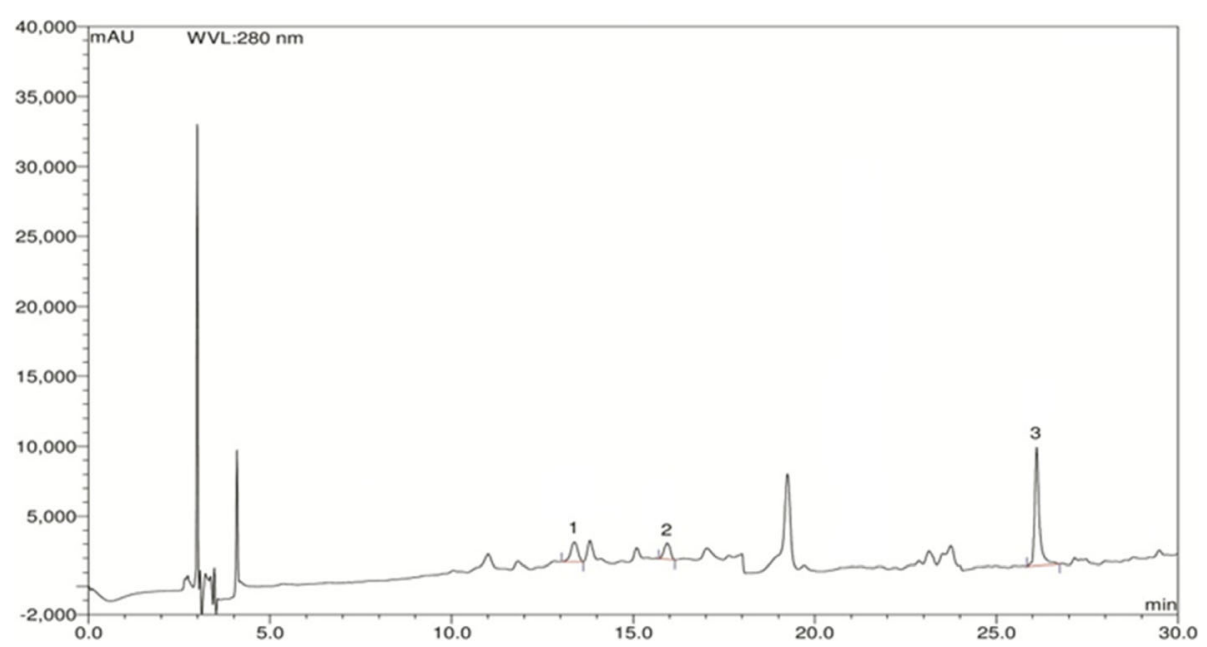

Fig. 5 HPLC chromatogram of ethanol extract of ZBRB. Here peaks indicate, 1: CT, 2: CA, 3: QU. Figure Sign: 1= (+)-catechin hydrate (CT), 2= caffeic acid (CA), 3= quercetin (QU) 
Table 3 Contents of polyphenolic compounds in the ethanol extract of ZBRB $(n=3)$

\begin{tabular}{lll}
\hline $\begin{array}{ll}\text { Polyphenolic } \\
\text { compound }\end{array}$ & Ethanol extract of ZBRB & \% RSD \\
\cline { 2 - 3 } & Content $(\mathrm{mg} / 100 \mathrm{~g}$ of extract $)$ & 0.41 \\
\hline $\mathrm{CT}$ & 17.94 & 0.02 \\
$\mathrm{CA}$ & 3.72 & 0.96 \\
\hline
\end{tabular}

chloride $\left(\mathrm{FeCl}_{3}\right)$, ferric-ferrous complex is formed as Prussian's blue and shows absorbance at $700 \mathrm{~nm}$. HPLC analysis was carried out to determine the presence of selected phenolic compounds of plant origin and subsequently catechin, caffeic acid and quercetin were found to be present in the extract (Table 3). Previous study demonstrated that catechin and quercetin contain the "ortho-3', 4'-dihydroxy structure in the B ring of their structure" which is an important feature that determines the antioxidant potential of flavonoids [21]. Caffeic acid was found to have potent antioxidant activity because of additional conjugation in the propenoic side chain, which can facilitate the electron delocalization capacity of aromatic ring by extending the conjugation [22]. Although only these three phenolic compounds were found to be present in ZBRB, presence of some peaks in the regions indicated that, the extract might have some compounds belonging to the class of simple polyphenols and catechins [23].

Analgesic activities of the ZBRB extract at both doses of 250 and $500 \mathrm{mg} / \mathrm{kg}$ were investigated both in acetic acid induced writhing and hot-plate model. These models are widely used to investigate both peripherally and centrally acting analgesic activity. Where, in writhing model ZBRB showed significant decrease in number of writhes dose dependently compared to control (Fig. 6) and in hot plate model, increased response time to pain stimulus compared to control (Fig. 7). Pain in acetic acid induced writhing is considered to occur through peripheral mechanisms whereas hot-plate model is associated with central mechanisms [24]. The release of local endogenous substances- $\mathrm{PGE}_{2}$, PGF2 $\alpha$ via cyclooxygenase (COX) pathway from membrane phospholipid as well as endogenous substances via lipoxygenase increases peritoneal fluids and reportedly responsible for Pain sensation in acetic acid induced writhing paradigm [25].
Abdominal writhing occurred in this paradigm due to the presence of local peritoneal receptor [26]. Result of the present study suggests that the extract might have potential analgesic activity by reducing prostaglandin synthesis through the inhibition of cyclooxygenase and lipoxygenase pathway. The result of hot-plate test suggests that the extract possesses central analgesic activity most probably in spinal cord level by binding with the receptors $(\mu, \delta$, and $\kappa)$ present in pre and post synaptic membrane [27]. Phenolic compounds detected in the HPLC analysis might also have some role in the central analgesia of the extract. Quercetin, an important flavonoid of medicinal plants, is known to have both antioxidant and analgesic effects by either inhibit nitric oxide production or deactivation of $y$-aminobutyric acid (GABA) or serotonin receptors or incitation of transient receptor potential cation channel subfamily $\mathrm{V}$ member 1 (TRPV1)/N-methyl-D-aspartate (NMDA) receptors or inhibit cytokine production and oxidative stress [28, 29]. Clinically this compound is also effective as a painkiller against painful bladder syndrome [30]. Early studies demonstrated that, catechins suppresses NF-kB activation and alleviates inflammation [31]. Caffeic acid is known to show anti-inflammatory activity by inhibiting arachidonic acid synthesis [32]. Caffeic acid has been claimed to be effective in combating inflammation and oxidative stress associated diseases through the inhibition of tumor promoter (12-O-tetradecanoylphorbo1-13-acetate)-induced processes [33]. Caffeic acid has also been found to show anti-inflammatory activity by blocking the gene expression and activity of cyclooxegenase-2 (COX-2) enzyme [34]. Nevertheless, the amount of caffeic acid in the extract and degree of analgesia makes it clear that, either some other compounds present in the extract are also responsible for this observed activity or each responsible compound synergistically enhance the effect of other responsible compound(s). Moreover, during the process of phagocytic action at the inflammatory sites, damaged inflammatory tissue discharge reactive oxygen species (ROS) and helps in the synthesis of prostaglandins from membrane phospholipids and thus the antioxidant compounds present in ZBRB also would have some role in the inhibition of ROS mediated inflammation [35, 36]. Besides, antioxidant compound(s), other group of secondary bioactive metabolites confirmed

Table 4 Effect of the extract of ZBRB on castor oil induced diarrhoea in mice

\begin{tabular}{lllll}
\hline Treatment $(n=6)$ & Dose $(\mathrm{mg} / \mathrm{kg})$ & Onset of diarrhoea $(\mathrm{min})$ & No. of stools after $4 \mathrm{~h}$ & $\%$ Inhibition of defecation \\
\hline Control & - & $34.00 \pm 3.15^{*}$ & $23.00 \pm 1.58^{*}$ & - \\
Loperamide & 3 & $198.60 \pm 2.34^{*}$ & $2.40 \pm 0.51^{*}$ & 89.56 \\
Extract & 250 & $101.40 \pm 3.39^{*}$ & $7.80 \pm 0.37^{*}$ & 66.56 \\
& 500 & $179.40 \pm 4.83^{*}$ & $3.80 \pm 0.49^{*}$ & 83.39
\end{tabular}

Results are expressed as mean \pm SEM, SEM Standard error for mean, $n=6$ (number of mice), ${ }^{*} P<0.001$ vs. control (Student's $t$-test) 


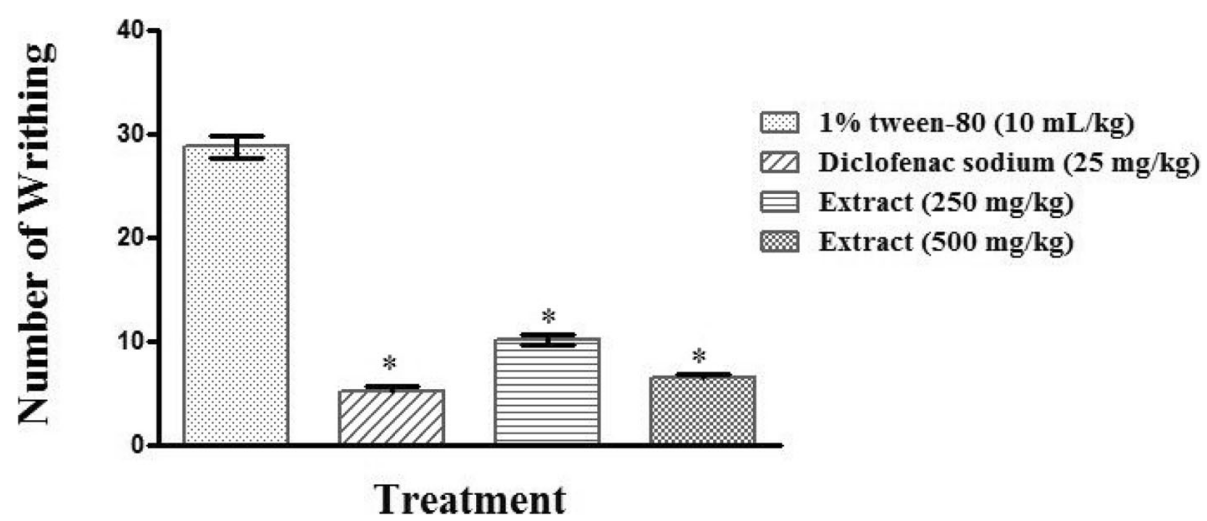

Fig. 6 Effect of ZBRB on acetic acid induced writhing in mice. Values are expressed as mean \pm SEM (Standard error for mean), $n=6$ (number of mice in each group), ${ }^{*} P<0.001$ vs. control (one-way ANOVA followed by Dunnett post-hoc test)

by preliminary phytochemical screening- flavonoid, alkaloid and steroid reportedly exhibit analgesic activity $[37,38]$. Since, it was a preliminary experiment; further more sophisticated investigation should be conducted to demonstrate possible compound(s) and their respective mechanism.

Diarrhoea is characterized by an increase in the frequency of defecation, number of watery stools and change in stool consistency [39]. It is one kind of gastrointestinal disorder in which gut motility or bowel movement is increased resulting in excess loss of fluids, electrolytes and nutrients [39, 40]. Castor oil induced diarrhoeal model was used in this study to evaluate antidiarrheal activity of the extract. Castor oil induces diarrhoea through the release of ricinolic acid which irritates the intestinal mucosa resulting in increased motility [41]. Beside this, castor oil also stimulates nitric oxide (NO) release which triggers the generation of prostaglandins by colonic cells exacerbating diarrhoea [42]. In this study, the result demonstrated that the ethanolic crude extract of ZBRB possess antidiarrheal activity (Table 4) which might be worth of presence of flavonoids and tannins in plant extract (Table 1) [43-45]. Flavonoids have been claimed to display antidiarrheal activity by the inhibition of intestinal motility and hydroelectrolytic secretions [46, 47]. The in vivo and in vitro experiment corroborated that flavonoid decline intestinal secretory response induced by prostaglandin E2 and contractions induced by spasmogens [48-50]. Flavonoids are also known to inhibit the release of autocoids and prostaglandins, hence, inhibiting the motility and secretion induced by castor oil $[51,52]$. In addition, flavonoids are belongs to antioxidant family to be responsible for the inhibition of several enzymes, such as those involved in arachidonic acid metabolism [53, 54]. Quercetin, a major flavonoid presence in the extract, could display

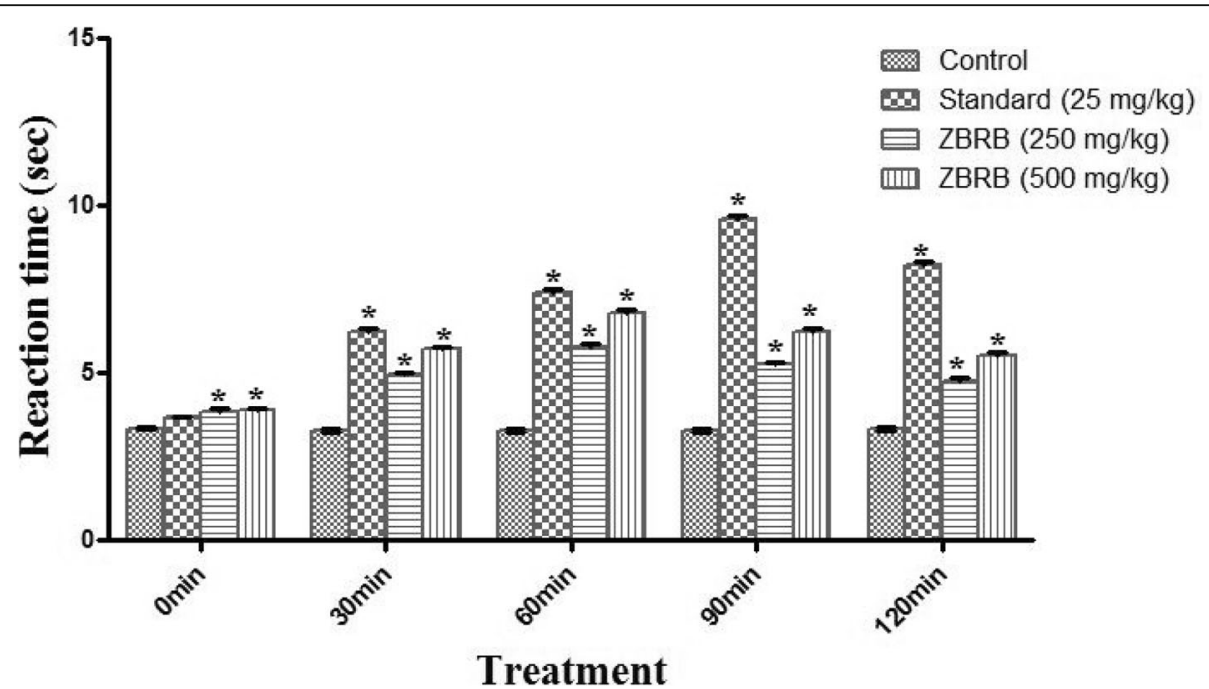

Fig. 7 Effect of ZBRB in hot-plate test in mice. Values are expressed as mean \pm SEM (Standard error for mean), $n=6$ (number of mice in each group), ${ }^{*} P<0.001$ vs. control (two way ANOVA followed by Bonferroni's post-hoc test) 


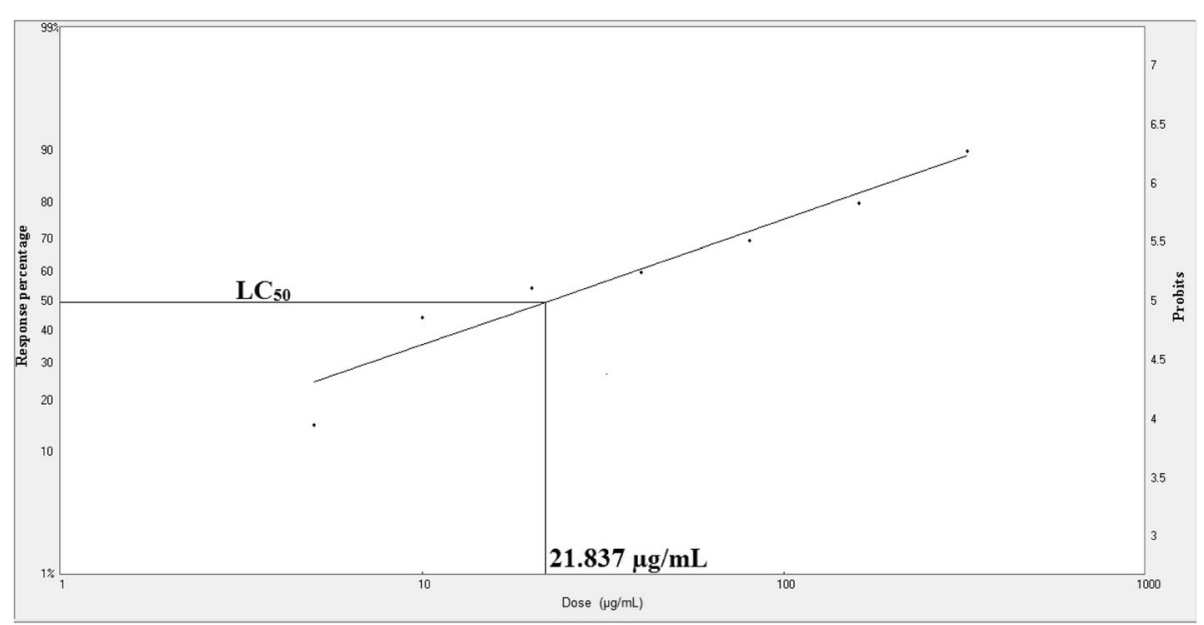

Fig. $8 L C_{50}$ value for the ethanolic extracts of Zanthoxylum budrunga root-bark

antidiarrheal activity by following either aforementioned mechanism of flavonoids $[55,56]$. The presence of tannins in the crude extract has also been reported to have antidiarrheal activity by reducing intestinal secretions induced by castor oil $[57,58]$.

Brine shrimp lethality bioassay is not only useful to examine the cytotoxic activity, but also a preliminary screening method to assess wide range of pharmacological activities including antimicrobial, pesticidal and antitumor activity of plant extracts [59]. It is widely used bench-top method because of the simple laboratory setup and small amount of sample is required [60]. The mechanism involved in the cytotoxicity of the brine shrimp can be of pharmacological effects linked to enzyme inhibition, ion channel interference or cytotoxicity $[12,61]$. In the present study the extract showed potential cytotoxic activity (Fig. 8) against brine shrimp nauplii in concentration dependent manner in comparison with standard drug, vincristine sulphate (Fig. 9). Since, the $\mathrm{LC}_{50}$ value of plant extract lower than $250 \mu \mathrm{g} / \mathrm{mL}$, the plant extract might be a potential source of diverse bioactive constituent(s) especially such as antimicrobial agent, anticancer agents, antimalarial drugs, insecticidal etc. [62, 63]. The polyphenolic compounds- catechin, caffeic acid and quercetin or other secondary metabolite presence (Table 1 ) in plant extract might be responsible in a single way or in combination way for the cytotoxic activity of the plant extract [63-67]. So, the purification of plant extract and elucidation of structures is crucial to ensure the exact mechanism(s) and compound(s) to conclude that of cytotoxic effect.

Though it is preliminary study report about phytoconstituents and possible bioactivities of ethanolic extract of Zanthoxylum budrunga root bark, it would beguile the attention of phytochemists for further isolation and characterization of bioactive

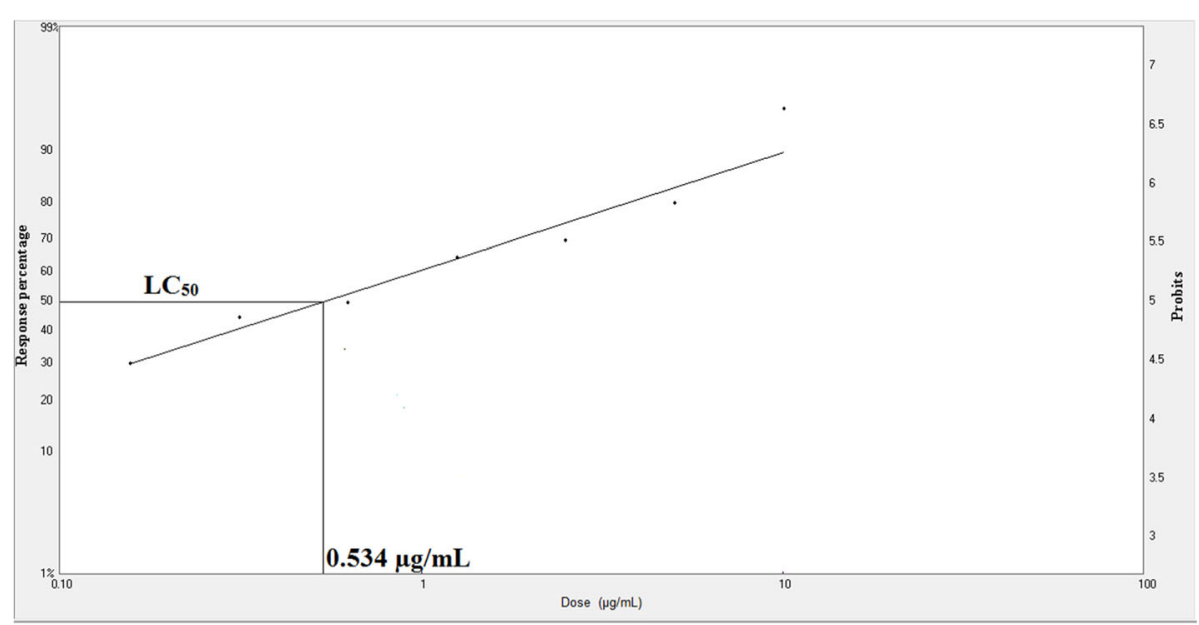

Fig. $9 L C_{50}$ value for vincristine sulphate 
constituents from this indigenous plant to discover new drug leads.

\section{Conclusion}

In the present study, the extract elaborated potential antioxidant, analgesic, antidiarrhoeal and cytotoxic activities in different in vivo and in vitro experimental models. The presence of some common phenolic compounds present in the extract might have some role in the observed pharmacological activities. The present investigation supports the use of $Z$. budrunga in traditional medicine. Metabolome based bioactivity guided phytochemical investigation can be done to find whether the observed bioactivity is linked to the well-known pytochemicals or because of the presence of novel chemical moieties.

\section{Abbreviations}

CA: Caffeic acid; CT: Catechin hydrate; DAD: Diode array detector; DMSO: Dimethyl sulfoxide; DPPH: 2: 2-diphenyl-1-picryldydrazyl; EA: Ellagic acid; EC: Epicatechin; GA: Gallic acid; GAE: Gallic acid equivalent; HPLC: High performance liquid chromatography; $I_{50}$ : $50 \%$ Inhibitory concentration; KF: Kaempferol; LC 50 : Median lethal concentration; MC: Myricetin; OD: Optical density; PCA: P-coumaric acid; QU: Quercetin; R $^{2}$ : Coefficient of determination; $\mathrm{RH}$ : Rutin hydrate; RSD: Relative standard deviation; VA: Vanillic acid

\section{Acknowledgements}

We are thankful to Pharmacy Discipline, Khulna University, Bangladesh for funding to conduct the present study. We are also grateful to Beximco Pharmaceuticals Ltd., Bangladesh for providing diclofenac sodium and to Jahangir University for supplying the experimental mice. The authors are also grateful to the authority of BCSIR for providing their HPLC instruments for analyzing the antioxidant compounds.

\section{Funding}

This project was supported by the B. Pharm laboratories' allocations of Pharmacy Discipline, Life Science School, Khulna University, Khulna, Bangladesh

\section{Availability of data and materials}

The datasets supporting the conclusions of this article are included within the article.

\section{Authors' contributions}

This work has been carried out in collaboration among authors. AKA performed the extraction and MKI performed the antioxidant and other pharmacological activities. SS and $\mathrm{HH}$ managed the literature searches, performed phytochemical screening, HPLC analysis and carried out the statistical analysis. JAS, AKD, and NNB designed the study. NNB and AKA drafted the manuscript. All authors read and approved the final manuscript.

\section{Authors' information}

Pharmacy Discipline, Life Science School, Khulna University, Bangladesh.

\section{Ethics approval}

In our study, Organization for Economic Cooperation and Development guidelines for the care and use of animals were followed. Our study was approved by a research Ethics Committee for Animal House of Pharmacy Discipline, Life Science School, Khulna University, Khulna-9208, Bangladesh. Three members ethics committee consists of Dr. Ashis Kumar Das, Professor and chairman of the committee (dasasish03@yahoo.com), Dr. jamil Ahmed Shilpi (jamilshilpi@yahoo.com),Professor and Dr. Sheikh Jamal Uddin, Associate Professor (uddinsj@yahoo.com); Pharmacy Discipline, Life Science School, Khulna University, Khulna-9208, Bangladesh. The approval reference number is: KU/PHARM/AEC/15/006/021.
Consent for publication

Not applicable.

\section{Competing interests}

The authors declare that they have no competing interests.

\section{Publisher's Note}

Springer Nature remains neutral with regard to jurisdictional claims in published maps and institutional affiliations.

\section{Author details}

${ }^{1}$ Pharmacy Discipline Life Science School, Khulna University, Khulna 9208 Bangladesh. ${ }^{2}$ Department of Biochemistry, Faculty of Mathematics and Natural Sciences, University of Turku, FI-20500 Turku, Finland. ${ }^{3}$ Department of Chemistry, Faculty of Mathematics and Natural Sciences, University of Turku, Turku FI-20014, Finland. ${ }^{4}$ BCSIR Laboratories \& IFST, Bangladesh Council of Scientific and Industrial Research (BCSIR), Dhaka 1205, Bangladesh.

Received: 1 June 2018 Accepted: 1 August 2018

Published online: 01 October 2018

\section{References}

1. Paul A, Arif M, Islam MT, Biswas S, Arif SM, Arifuzzaman S, et al. Preventive medicinal plants consumed by the rural population of Bangladesh-a randomized survey of Silakhana village in Bagerhat district. Eur J Sustain Agric. 2012:6(4):276-80.

2. Islam MK, Saha S, Mahmud I, Mohamad K, Awang K, Uddin SJ, et al. An ethnobotanical study of medicinal plants used by tribal and native people of Madhupur forest area, Bangladesh. J Ethnopharmacol. 2014;151(2):921-30.

3. Thappa R, Dhar K, Atal C. A new monoterpene triol from Zanthoxylum budrunga. Phytochemistry. 1976;15(10):1568-9.

4. Islam A, Sayeed A, Bhuiyan M, Mosaddik M, Islam M, Khan GAM. Antimicrobial activity and cytotoxicity of Zanthoxy/um budrunga. Fitoterapia. 2001;72(4):428-30

5. Rana V, Blazquez MA. Volatile constituents of the seed coat of Zanthoxylum rhetsa (Roxb.) DC. J Essent Oil Res. 2010;22(5):430-2.

6. Medicinal Plants of Bangladesh: http://www.mpbd.info/plants/zanthoxylumrhetsa.php. Accessed 31 April 2018.

7. Ghani A. Medicinal plants of Bangladesh: chemical constituents and uses: Asiatic Society of Bangladesh; 1998

8. Biswas NN, Acharzo AK, Anamika S, Khushi S, Bokshi B. Screening of Natural Bioactive Metabolites and Investigation of Antioxidant, Antimicrobial, Antihyperglycemic, Neuropharmacological, and Cytotoxicity Potentials of Litsea polyantha Juss. Ethanolic Root Extract. Evid Based Complement Alternat Med. 2017;217. https://doi.org/10.1155/2017/3701349.

9. Wolfe K, Wu X, Liu RH. Antioxidant activity of apple peels. J Agric Food Chem. 2003;51(3):609-14

10. Oyaizu M. Studies on products of browning reaction--antioxidative activities of products of browning reaction prepared from glucosamine. Jpn J Nutr. 1986:44(6):307-15.

11. Islam MK, Biswas NN, Saha S, Hossain H, Jahan IA, Khan TA, et al. Antinociceptive and antioxidant activity of Zanthoxylum budrunga wall (rutaceae) seeds. Sci World J 2014;2014. http://dx.doi.org/10.1155/2014/869537.

12. Anisuzzman M, Hasan $M$, Acharzo AK, Das AK, Rahman S. In Vivo and In Vitro evaluation of pharmacological potentials of secondary bioactive metabolites of Dalbergia candenatensis leaves. Evid Based Complement Alternat Med. 2017:2017:1-10

13. Mondal H, Saha S, Awang K, Hossain H, Ablat A, Islam MK, et al. Centralstimulating and analgesic activity of the ethanolic extract of Alternanthera sessilis in mice. BMC Complement Altern Med. 2014;14(1):398.

14. Meyer B, Ferrigni N, Putnam J, Jacobsen L, Nichols DJ, McLaughlin JL. Brine shrimp: a convenient general bioassay for active plant constituents. Planta Med. 1982;45(05):31-4

15. Talukder C, Saha S, Adhikari S, Mondal HK, Islam MK, Anisuzzman M Evaluation of antioxidant, analgesic and antidiarrhoeal activity of Flacourtia jangomas (Lour.) Raeusch. Leaves. Pharmacologyonline. 2012;3:20-8.

16. Lobo V, Patil A, Phatak A, Chandra N. Free radicals, antioxidants and functional foods: impact on human health. Pharmacogn Rev. 2010:4(8):118

17. Krishnaiah D, Sarbatly R, Nithyanandam R. A review of the antioxidant potential of medicinal plant species. Food Bioprod Process. 2011;89(3): 217-33 
18. Wang K-J, Yang C-R, Zhang Y-J. Phenolic antioxidants from Chinese toon (fresh young leaves and shoots of Toona sinensis). Food Chem. 2007;101(1):365-71.

19. Mhadhebi L, Mhadhebi A, Robert J, Bouraoui A. Antioxidant, anti-inflammatory and antiproliferative effects of aqueous extracts of three mediterranean brown seaweeds of the genus cystoseira. Iran J Pharm Res. 2014;13(1):207.

20. Yen GC, Duh PD, Tsai CL. Relationship between antioxidant activity and maturity of peanut hulls. J Agric Food Chem. 1993;41(1):67-70.

21. Meir S, Kanner J, Akiri B, Philosoph-Hadas S. Determination and involvement of aqueous reducing compounds in oxidative defense systems of various senescing leaves. J Agric Food Chem. 1995;43(7):1813-9.

22. Lee S-M, Lin J-J, Liao C-Y, Cheng H-L, Sun PB. Phenolic acids identified in sorghum distillery residue demonstrated antioxidative and anti-cold-stress properties in cultured tilapia, Oreochromis mossambicus. J Agric Food Chem. 2014;62(20):4618-24.

23. Wojdyło A, Oszmiański J, Czemerys R. Antioxidant activity and phenolic compounds in 32 selected herbs. Food Chem. 2007;105(3):940-9.

24. Yu H-L, Li Y-J, Gong G-H, Quan Z-S. Anti-inflammatory and antinociceptive effects of 6-(4-chlorophenoxy)-tetrazolo [5, 1-a] phthalazine in mice. Pharmacol Rep. 2012;64(5):1155-65.

25. Muhammad N. In-vivo models for management of pain. Pharmacol Pharm 2014;5(01):92.

26. Mbiantcha M, Kamanyi A, Teponno R, Tapondjou A, Watcho P, Nguelefack T. Analgesic and anti-inflammatory properties of extracts from the bulbils of Dioscorea bulbifera L. var sativa (Dioscoreaceae) in mice and rats. Evid Based Complement Alternat Med. 2011;2011. http://dx.doi.org/10.1155/2011/912935.

27. Abbott FV, Melzack R. Brainstem lesions dissociate neural mechanisms of morphine analgesia in different kinds of pain. Brain Res. 1982;251(1):149-55.

28. Valerio DA, Georgetti SR, Magro DA, Casagrande R, Cunha TM, Vicentini FT, et al. Quercetin reduces inflammatory pain: inhibition of oxidative stress and cytokine production. J Nat Prod. 2009;72(11):1975-9.

29. Borghi SM, Pinho-Ribeiro FA, Fattori V, Bussmann AJ, Vignoli JA, CamiliosNeto D, et al. Quercetin inhibits peripheral and spinal cord nociceptive mechanisms to reduce intense acute swimming-induced muscle pain in mice. PLoS One. 2016;11(9):e0162267.

30. Andurkar SV, Gendler L, Gulati A. Tramadol antinociception is potentiated by clonidine through a2-adrenergic and 12 -imidazoline but not by endothelin ETA receptors in mice. Eur J Pharmacol. 2012;683(1-3):109-15.

31. Ravindranath NH, Ravindranath MH. Green tea catechins suppress NF-kBmediated inflammatory responses: relevance to nutritional management of inflammation. Br J Nutr. 2011;105(12):1715-7.

32. Theoharides TC. Treatment approaches for painful bladder syndrome/ interstitial cystitis. Drugs. 2007;67(2):215-35.

33. Ozturk G, Ginis Z, Akyol S, Erden G, Gurel A, Akyol O. The anticancer mechanism of caffeic acid phenethyl ester (CAPE): review of melanomas, lung and prostate cancers. Eur Rev Med Pharmacol Sci. 2012;16(15):2064-8.

34. Michaluart P, Masferrer JL, Carothers AM, Subbaramaiah K, Zweifel BS, Koboldt $C$, et al. Inhibitory effects of caffeic acid phenethyl ester on the activity and expression of cyclooxygenase- 2 in human oral epithelial cells and in a rat model of inflammation. Cancer Res. 1999;59(10):2347-52.

35. Bae J-S, Kim TH. Enzymatic transformation of caffeic acid with enhanced cyclooxygenase-2 inhibitory activity. Bioorg Med Chem Lett. 2012;22(2):793-6.

36. Parke D, Sapota A. Chemical toxicity and reactive oxygen species. Int J Occup Med Environ Health. 1996;9(4):331-40.

37. Kumar S, Pandey AK. Chemistry and biological activities of flavonoids: an overview. Sci World J. 2013:2013

38. Bhaskar V, Balakrishnan N. Analgesic, anti-inflammatory and antipyretic activities of Pergularia daemia and Carissa carandas. DARU J Pharm Sci. 2009;17(3):168-74.

39. Ferdous M, Rouf R, Shilpi JA, Uddin SJ. Antinociceptive activity of the ethanolic extract of Ficus racemosa Lin.(Moraceae). Orient Pharm Exp Med. 2008:8(1):93-6.

40. Dey SK, Hira A, Howlader MSI, Ahmed A, Hossain H, Jahan IA. Antioxidant and antidiarrheal activities of ethanol extract of Ardisia elliptica fruits. Pharm Biol. 2014;52(2):213-20.

41. Mahalanabis D, Merson M, Barua D. Oral rehydration therapy--recent advances: World health forum. 1981;2(2):245-9.

42. Pierce NF, Carpenter CC, Elliott HL, Greenough WB. Effects of prostaglandins, theophylline, and cholera exotoxin upon transmucosal water and electrolyte movement in the canine jejunum. Gastroenterology. 1971;60(1):22-32.

43. Umer S, Tekewe A, Kebede N. Antidiarrhoeal and antimicrobial activity of Calpurnia aurea leaf extract. BMC Complement Altern Med. 2013;13(1):21.
44. Otshudi AL, Vercruysse A, Foriers A. Contribution to the ethnobotanical, phytochemical and pharmacological studies of traditionally used medicinal plants in the treatment of dysentery and diarrhoea in Lomela area, Democratic Republic of Congo (DRC). J Ethnopharmacol. 2000;71(3):411-23.

45. Malterud KE, Samuelsen AB, Alamgir M, Klarpås L, Wangensteen H. Can scientific evidence support using Bangladeshi traditional medicinal plants in the treatment of Diarrhoea\&63; A Review on Seven Plants. Nutrients. 2013;5(5): 1757-800.

46. Rao V, Santos F, Sobreira T, Souza M, Melo C, Silveira E. Investigations on the gastroprotective and antidiarrhoeal properties of ternatin, a tetramethoxyflavone from Egletes viscosa. Planta Med. 1997:63(02):146-9.

47. Carlo G, Izzo A, Maiolino P, Mascolo N, Viola P, Diurno M, et al. Inhibition of intestinal motility and secretion by flavonoids in mice and rats: structureactivity relationships. J Pharm Pharmacol. 1993;45(12):1054-9.

48. de Medina L-HFS, Gálvez J, González M, Zarzuelo A, Barrett KE. Effects of quercetin on epithelial chloride secretion. Life Sci. 1997;61(20):2049-55.

49. Macauder P. Flavonoids affect acetylcholine, prostaglandin $\mathrm{E}$ and antigen mediated muscle contration. Prog Clin Biol Res. 1986;231:489-92.

50. Capasso F, Pinto A, Mascolo N, Autore G, Franco F. Effect of flavonoids on PAG2 - and LTD4_induced contractions on the Guinea-pig isolated ileum. Pharmacol Res Commun. 1988;20:201-2.

51. Vimala R, Nagarajan S, Alam M, Susan T, Joy S. Antiinflammatory and antipyretic activity of Michelia champaca Linn.,(white variety), Ixora brachiata Roxb. And Rhynchosia cana (Willd.) DC flower extract. Indian J Exp Biol. 1997; 35(12):1310-4

52. Nikiema J, Vanhaelen-Fastré R, Vanhaelen M, Fontaine J, De Graef C, Heenen M. Effects of antiinflammatory triterpenes isolated from Leptadenia hastata latex on keratinocyte proliferation. Phytother Res. 2001;15(2):131-4.

53. Mora A, Paya M, Rios J, Alcaraz M. Structure-activity relationships of polymethoxyflavones and other flavonoids as inhibitors of non-enzymic lipid peroxidation. Biochem Pharmacol. 1990;40(4):793-7.

54. Su Y-L, Leung LK, Bi Y-R, Huang Y, Chen Z-Y. Antioxidant activity of flavonoids isolated from Scutellaria rehderiana. J Am Oil Chem Soc. 2000:77(8):807-13.

55. Venkatesan N, Thiyagarajan V, Narayanan S, Arul A, Raja S, Kumar SV, et al. Anti-diarrhoeal potential of Asparagus racemosus wild root extracts in laboratory animals. J Pharm Pharm Sci. 2005;8(1):39-46.

56. Weng C-J, Yen G-C. Flavonoids, a ubiquitous dietary phenolic subclass, exert extensive in vitro anti-invasive and in vivo anti-metastatic activities. Cancer Metastasis Rev. 2012;31(1-2):323-51.

57. Tripathi K. Essentials of medical pharmacology. Indian J Pharmacol. 1994;26(2):166

58. Atta AH, Mouneir SM. Evaluation of some medicinal plant extracts for antidiarrhoeal activity. Phytother Res. 2005;19(6):481-5.

59. Saha S, Anisuzzman M, Islam MK, Mondal H, Talukder C. Antibacterial and cytotoxic potential of Dalbergia spinosa Roxb. leaves. Int J Pharm Sci Res. 2013:4(1):512.

60. Siraj M, Chakma N, Rahman M, Malik S, Sadhu S. Assessment of analgesic, antidiarrhoeal and cytotoxic activity of ethanolic extract of the whole plant of Bacopa monnieri Linn. Int Res J Pharm. 2012:3:98-101.

61. Anderson J, Goetz C, McLaughlin J, Suffness M. A blind comparison of simple bench-top bioassays and human tumour cell cytotoxicities as antitumor prescreens. Phytochem Anal. 1991;2(3):107-11.

62. Rieser MJ, Gu Z-M, Fang X-P, Zeng L, Wood KV, McLaughlin JL. Five novel mono-tetrahydrofuran ring acetogenins from the seeds of Annona muricata. J Nat Prod. 1996;59(2):100-8.

63. Dusen S, Aydin C, Gul HY, Ozay C, Dusen O, Mammadov R. In vitro cytotoxic activities of Cyclamen L.(primulaceae) ethanol extracts from turkey. Fresen Environ Bull. 2016:25(12 A):6224-8.

64. Nakazato T, Ito K, Ikeda Y, Kizaki M. Green tea component, catechin, induces apoptosis of human malignant B cells via production of reactive oxygen species. Clin Cancer Res. 2005;11(16):6040-9.

65. Gomes CA, Girão da Cruz T, Andrade JL, Milhazes N, Borges F, Marques MPM. Anticancer activity of phenolic acids of natural or synthetic origin: a structure- activity study. J Med Chem. 2003;46(25):5395-401.

66. Sanderson JT, Clabault H, Patton C, Lassalle-Claux G, Jean-François J, Paré $A F$, et al. Antiproliferative, antiandrogenic and cytotoxic effects of novel caffeic acid derivatives in LNCaP human androgen-dependent prostate cancer cells. Bioorg Med Chem. 2013;21(22):7182-93.

67. Musa AA. Cytotoxicity activity and phytochemical screening of Cochlospermum tinctorium Perr Ex A. rich rhizome. J App Pharm Sci. 2012;2: $155-9$. 